\title{
Comparison of Bacterial Loads from the Lift Buttons of a Kulliyyah and a Library at IIUM Kuantan and Identification of the Bacteria from Selected Buildings
}

\author{
Nur Izzatul Husna Mohd Danial ${ }^{1}$, Norsyuhada Alias ${ }^{1}$, Fadhlin Sakina Mohd Fauzi ${ }^{1}$ \\ ${ }^{1}$ Department of Biomedical Sciences, Kulliyyah of Allied Health Sciences, \\ International Islamic University Malaysia
}

Presenter: Nur Izzatul Husna Mohd Danial

Introduction: Lift buttons are among the potential fomites in transmitting infectious microorganism to the community. The daily use of lift buttons by different people with various hygiene practices can contribute to the colonization of microorganism on the touched surfaces. There is a little published research on microbial colonization on lift buttons in Malaysia, especially in the campus setting. Hence, this study aimed to identify and compare the bacterial load on lift buttons from a kulliyyah (faculty) and the library at IIUM Kuantan. Materials and Methods: A total of 42 swab samples were collected aseptically from the lift buttons and cultured on nutrient, mannitol salt and MacConkey agar for bacterial enumeration and isolation. Gram staining, microscopy examination and molecular amplification of the 16S rDNA gene by polymerase chain reaction were performed for further characterization of the bacteria. Results: Out of 42 swab samples collected (kulliyyah: $n=25$, library: $n=17$ ), $88.4 \%$ of the samples confirmed the presence of bacteria with the lift buttons in the kulliyyah showed a higher percentage of bacterial isolation (92\%) compared to the library (84\%). Grampositive cocci clustered bacteria dominated the isolates followed by Gram-positive bacilli, Gram-positive cocci tetrads and Gram-negative coccobacilli. Based on culture growth, Gram-staining features and 16S rDNA gene sequencing, isolated bacteria were identified as Staphylococcus sp., Staphylococcus kloosii, Bacillus cereus, Kocuria palustris, Yersinia mollaretii, Bacillus sp., Micrococcus sp., and other Gram-positive cocci. Conclusion: The results revealed a high bacterial load on lift buttons which can be a source of bacterial transmission. 